\title{
A concise and practical stereoselective synthesis of ipragliflozin L-proline
}

\author{
Shuai Ma, Zhenren Liu, Jing Pan, Shunli Zhang and Weicheng Zhou*
}

\section{Full Research Paper}

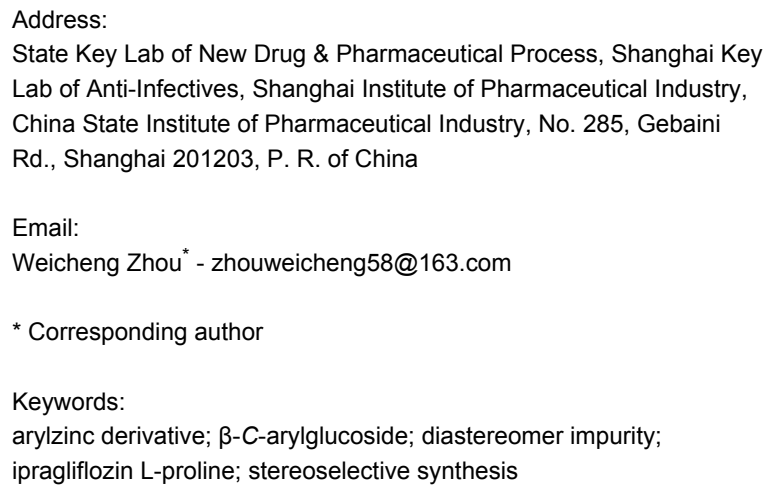

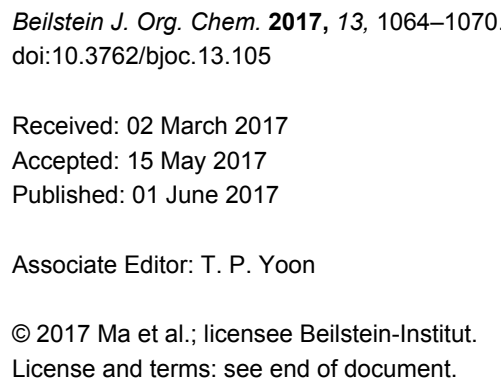

\begin{abstract}
A concise and practical stereoselective synthesis of ipragliflozin L-proline was presented starting from 2-[(5-iodo-2fluorophenyl)methyl]-1-benzothiophene and 2,3,4,6-tetra- $O$-pivaloyl- $\alpha$-D-glucopyranosyl bromide without catalyst via iodine-lithium-zinc exchange. The overall yield was $52 \%$ in three steps and the product purity was excellent. Two key diastereomers were prepared with efficient and direct access to the $\alpha$ - $C$-arylglucoside.
\end{abstract}

\section{Introduction}

Sodium-glucose co-transporter 2 (SGLT2) inhibitors are a new class of antidiabetes drugs, and dapagliflozin [1], canagliflozin [2], empagliflozin [3], ipragliflozin [4], tofogliflozin [5], luseogliflozin [6] have been approved for the treatment of Type 2 diabetes mellitus (T2DM). One of them, (ipragliflozin L-proline 1, (1S)-1,5-anhydro-1-C-\{3-[(1-benzothiophen-2yl)methyl]-4-fluorophenyl $\}$-D-glucitol (2S)-pyrrolidine-2carboxylic acid (1:1), Figure 1), was launched into the Japanese market in January 2014 [7,8]. Due to its efficacy and safety, 1 can be used as monotherapy or in combination with other hypoglycemic agents.
Only a few methods have been found in the literature about the synthesis of $\mathbf{1}$. It was reported that aryllithium reacted with perhydroxy-protected D-glucono-1,5-lactone at $-78{ }^{\circ} \mathrm{C}$ to obtain the lactol, followed by reduction with a large bulk silyl hydride in order to get high $\beta$-selectivity $[9,10]$. This approach included six steps such as addition, methyl etherification, acetylation, reduction, deprotection and cocrystallization with L-proline to get 1 with a total yield of $32.89 \%$. The subsequent improvement reported included the replacement of aryllithium by aryl Grignard reagents, raising the reaction temperature up to $-20^{\circ} \mathrm{C}$ [11]. However, the yield was not obviously improved. 
<smiles>O=C(O)C1CCCN1</smiles>

Figure 1: Structure of ipragliflozin L-proline.

SGLT-2 inhibitors have the common pharmacophore of $\beta$ - $C$ arylglucoside, and the synthesis of $\beta$ - $C$-arylglucoside including the usage of arylzinc [12], arylalane [13], and anomeric stannane [14] were applied to prepare dapagliflozin and canagliflozin. However, these approaches might be difficult to scale up because of the involvements of complex synthetic procedures, chromatographic purification or expensive catalysts and ligands. Gong et al. [15] reported an approach to synthesise $C$-aryl glycosides based on a Negishi cross-coupling of arylzinc with protected glycosyl bromide in the presence of $\mathrm{Ni}$-catalysts. An improved procedure with high stereoselectivity and in the absence of catalysts was reported subsequently by Lemarie et al. (Scheme 1) [12] to construct the anomeric chiral center of dapagliflozin and canagliflozin. But so far, it has not been found that this method was applied to synthesize 1. In this paper, we report an efficient and practical method for the preparation of $\mathbf{1}$ through an arylzinc reagent.

\section{Results and Discussion}

Herein, a concise and practical stereoselective synthesis of $\mathbf{1}$ with three steps was developed. The route initiated from compound $4 \mathbf{a}$ and pivaloyl-protected glycosyl bromide $\mathbf{2} \mathbf{b}$, the $\beta-C$ arylglucoside $\mathbf{5}$ was obtained with high stereoselectivity in one step after a halogen-lithium exchange/transmetalation/coupling

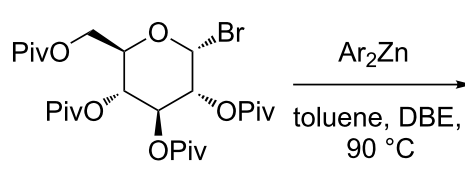

2b

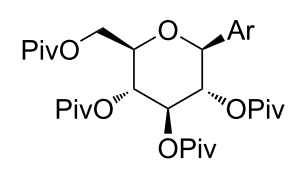

3
Scheme 1: Stereoselective synthesis of $C$-aryl glycoside by Lemarie.

sequence. Cryogenic temperatures and catalysts were not required.

The key step was the diastereoselective synthesis of pivaloylprotected 5 (Scheme 2). Thus, this reaction was studied in more detail to screen the best conditions, and the results were presented in Table 1.

On the basis of literature [12], 2-[(5-bromo-2-fluorophenyl)methyl]-1-benzothiophene (4b) [9] was converted to the arylzinc species by the reaction with $n$-BuLi in the mixed solvent (toluene/DBE), followed by transmetalation with $\mathrm{ZnBr}$ / $\mathrm{LiBr}$ complex in DBE, and then the active species reacted with 2,3,4,6-tetra- $O$-pivaloyl- $\alpha$-D-glucopyranosyl bromide (2b) [16]. But the reaction gave only $35 \%$ of desired 5 although it had a high diastereomeric excess (de) value (97\%). The main byproduct was the debrominated compound 5 " determined by NMR and MS analysis (Table 1, entry 1). The reaction between 2-[(5iodo-2-fluorophenyl)methyl]-1-benzothiophene (4a) [9] and pivaloyl-protected glycosyl halides 2 were further explored. The reaction of chloride 2c [17] with $\mathbf{4 a}$ provided a better result (Table 1, entry 2). With respect to the iodide $\mathbf{2 a}$ [18], due to its thermal and chemical instability, there was only $2 \%$ of 5 detected, and the content of $\mathbf{5}$ " was up to $60 \%$ (Table 1, entry 3 ). Fortunately, the reaction of $\mathbf{4 a}$ with 1.0 equiv $\mathbf{2 b}$ gave a good result, the amount of $\mathbf{5}$ " was greatly reduced (Table 1, entry 4), while the content of $\mathbf{5}$ in the crude product was in-<smiles>[R]c1ccc(F)c(Cc2cc3ccccc3s2)c1</smiles> 
Table 1: Conditions for the stereoselective synthesis of $\beta$ - $C$-arylglucoside 5.

\begin{tabular}{|c|c|c|c|c|c|c|c|}
\hline Entry & Reactants & Zinc halide salt & Solvent & $T\left({ }^{\circ} \mathrm{C}\right)$ & Crude product $^{\mathrm{a}}\left(5: 5^{\prime}: 5^{\prime \prime}\right)$ & $\mathrm{de}^{\mathrm{b}}(\%)$ & Yield $\mathrm{C}(\%)$ \\
\hline 1 & $4 b, 2 b$ & $\mathrm{ZnBr}_{2} / \mathrm{LiBr}$ ( 0.55 equiv) & Toluene/DBE $^{d}(5: 3)$ & -20 & $35 \%: 0.5 \%: 46 \%$ & 97 & 48.4 \\
\hline 2 & $4 a, 2 c$ & $\mathrm{ZnBr}_{2} / \mathrm{LiBr}$ ( 0.55 equiv) & Toluene/DBE (5:3) & -20 & $50 \%: 4 \%: 36 \%$ & 85 & 63.8 \\
\hline 3 & $4 a, 2 a$ & $\mathrm{Znl}_{2} / \mathrm{Lil}$ (0.55 equiv) & Toluene/DBE (5:3) & -20 & $2 \%: 0.3 \%: 60 \%$ & 74 & - \\
\hline 4 & $4 a, 2 b$ & $\mathrm{ZnBr}_{2} / \mathrm{LiBr}$ ( 0.55 equiv) & Toluene/DBE (5:3) & -20 & $68 \%: 2 \%: 21 \%$ & 94 & 77.7 \\
\hline 5 & $4 a, 2 b$ & $\mathrm{ZnBr}_{2} / \mathrm{LiBr}$ (1.0 equiv) & Toluene/DBE (5:3) & -20 & $65 \%: 2 \%: 24 \%$ & 94 & 75.6 \\
\hline 6 & $4 a, 2 b$ & $\mathrm{ZnBr}_{2} / \mathrm{LiBr}(0.55$ equiv $)$ & Toluene/DBE (5:3) & -10 & 34\%:1\%:46\% & 94 & 46.7 \\
\hline 7 & $4 a, 2 b$ & $\mathrm{ZnBr}_{2} / \mathrm{LiBr}(0.55$ equiv $)$ & Toluene/DBE (5:3) & -30 & $67 \%: 2 \%: 23 \%$ & 94 & 76.5 \\
\hline $8^{e}$ & $4 a, 2 b$ & $\mathrm{ZnBr}_{2} / \mathrm{LiBr}$ ( 0.55 equiv $)$ & Toluene/DBE (5:3) & -20 & $55 \%: 2 \%: 32 \%$ & 93 & 78.9 \\
\hline $9^{f}$ & $4 a, 2 b$ & $\mathrm{ZnBr}_{2} / \mathrm{LiBr}(0.55$ equiv) & Toluene/DBE (5:3) & -20 & $68 \%: 2 \%: 20 \%$ & 94 & 77.9 \\
\hline 10 & $4 a, 2 b$ & $\mathrm{ZnBr}_{2} / \mathrm{LiBr}$ (0.55 equiv) & Toluene/THF (5:3) & -20 & 2\%:0\%:14\% & 09 & - \\
\hline 11 & $4 a, 2 b$ & $\mathrm{ZnBr}_{2} / \mathrm{LiBr}(0.55$ equiv $)$ & Toluene/MTBE ${ }^{\mathrm{h}}(5: 3)$ & -20 & 5\%:0\%:67\% & 09 & 6.5 \\
\hline 12 & $4 a, 2 b$ & $\mathrm{ZnBr}_{2} / \mathrm{LiBr}$ ( 0.55 equiv) & Toluene/CPME' $(5: 3)$ & -20 & $33 \%: 0.4 \%: 49 \%$ & 98 & 47 \\
\hline $13^{\mathrm{j}}$ & $4 a, 2 b$ & $\mathrm{ZnBr}_{2} / \mathrm{LiBr}$ ( 0.55 equiv) & Toluene/DBE (5:3) & -20 & $66 \%: 2 \%: 22 \%$ & 94 & $62.8^{\mathrm{k}}$ \\
\hline $14^{1}$ & $4 a, 2 b$ & $\mathrm{ZnBr}_{2} / \mathrm{LiBr}$ ( 0.55 equiv) & Toluene/DBE $(5: 3)$ & -20 & $68 \%: 2.5 \%: 21 \%$ & 93 & $65.3^{\mathrm{k}}$ \\
\hline
\end{tabular}

aDetermined by HPLC at $263 \mathrm{~nm}$, the content of 5" might be over-estimated since the different UV response between compound $\mathbf{5}$ and $\mathbf{5}$ ". This may

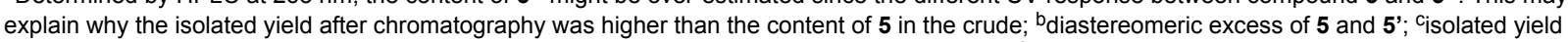
for $\mathbf{5}$ after column chromatography (entries $1-12$ ); ${ }^{d}$ di- $n$-butyl ether; ${ }^{\mathbf{e}} \mathbf{4 a}$ was added in 1.2 equiv; ${ }^{\mathbf{2}} \mathbf{b}$ was added in 1.2 equiv; ${ }^{9}$ no diastereomer was

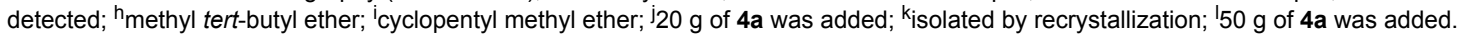

creased to $68 \%$ and the isolated yield was $77.7 \%$. It was presumable that a iodine-lithium-zinc exchange and the transmetalation proceeded better than a bromide-lithium-zinc exchange and transmetalation to produce the arylzinc derivative in situ in this reaction. However, further increasing the amount of zinc bromide to 1.0 equiv did not improve the reaction (Table 1, entry 5) and elevation of the reaction temperature to $-10{ }^{\circ} \mathrm{C}$ (Table 1 , entry 6 ) worsened the reaction, resulting in more formation of 5', Additionally, no significant improvement was achieved by further decreasing the temperature (Table 1, entry 7).

In entries 1-7 (Table 1), the feed ratio of two reagents (4 and 2 ) was set as $1: 1$. From the above data, it was seen that the reaction was accompanied by the deiodination of $\mathbf{4 a}$, but to our surprise, neither elevation of the ratio to 1.2 of compound $\mathbf{4 a}$ (Table 1, entry 8) nor $\mathbf{2 b}$ (Table 1, entry 9) improved the reaction. When other solvents were tested (Table 1, entries 10-12), the results showed that the reaction in toluene/DBE mixed solvent afforded the best result. Interestingly, it was also found that the reaction of $\mathbf{2 b}$ with $\mathbf{4} \mathbf{a}$ gave a similar de (Table 1, entries 1 , 4-9 and 12-14) in different conditions although the content of 5 was greatly varied. According to the methodology in entry 4, the reaction was scaled up (50 g 4a) (Table 1, entry 14), and the crude product was purified by recrystallization from methanol, and the desired product in $65.3 \%$ yield with HPLC purity $99.79 \%$ was obtained; the diastereomer 5' was not detected.
The protecting groups of $\mathbf{5}$ were removed in presence of sodium methoxide in refluxing methanol, and then recrystallized to give ipragliflozin $\mathbf{6}$ in $95.3 \%$ yield. Compound $\mathbf{6}$ and L-proline was converted to the L-proline complex $\mathbf{1}$ as a cocrystal form in ethanol (Scheme 3). After filtration and drying, compound 1 was produced with $83.7 \%$ yield and $99.92 \%$ purity. The mp (dec) and optical rotation value of compound 1 was consistent with those in the literature reported [19], and the structure was confirmed by MS and NMR.

The $\alpha$-anomers of 5 and $\mathbf{6}$ were the key impurities during the synthetic process. Pure compounds of 5' and 6' were prepared for the analytical references (Scheme 4). Compound 4a was converted to the corresponding arylzinc derivative in situ, and the latter coupled with pivaloyl-protected 1,2-anhydroglucal 7 [20] to get the $\alpha-C$-arylglucoside 8. After removing the protecting groups in the presence of sodium methoxide, the $\alpha$-anomer 6' of ipragliflozin was obtained. The hydroxy group in 2-position of $\mathbf{8}$ was protected by pivaloyl chloride to generate 5'. In the ${ }^{1} \mathrm{H}$ NMR, the coupling constant of the anomeric proton for 6' was $4.0 \mathrm{~Hz}$, while the corresponding constant for $\mathbf{6}$ was $9.6 \mathrm{~Hz}$, which was similar with those of canagliflozin [20].

\section{Conclusion}

In conclusion, a concise and practical stereoselective synthesis of $\mathbf{1}$ starting from $\mathbf{4 a}$ and $\mathbf{2 b}$ was developed in a $52 \%$ overall yield with a purity of $99.92 \%$ over three steps. This method was easy to perform in large scale, and both the purity and yield 


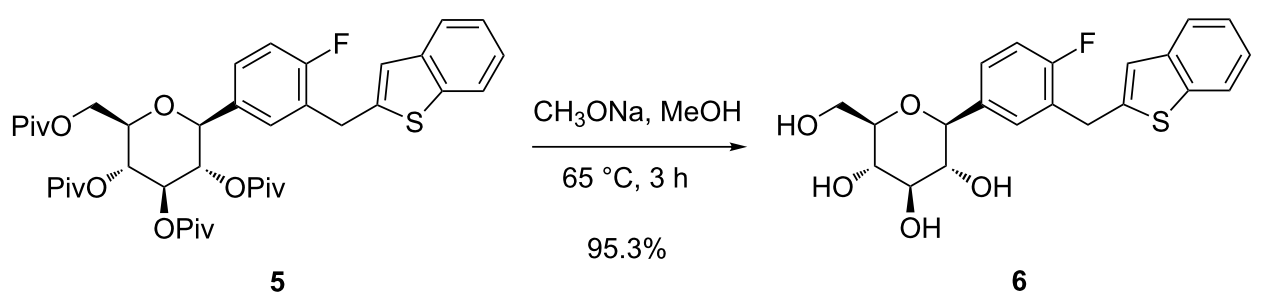<smiles>O=C(O)C1CCCN1</smiles><smiles>Fc1ccc(I)cc1Cc1cc2ccccc2s1</smiles>

4a

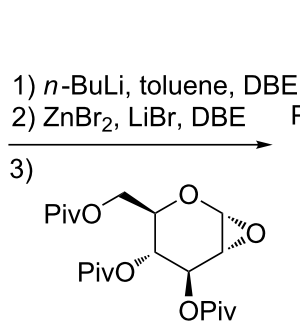

7

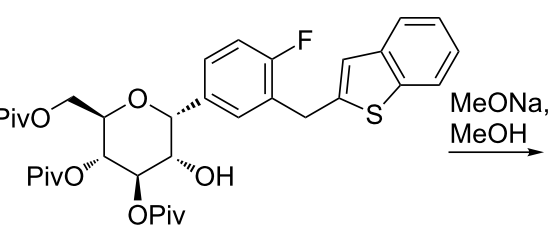

8<smiles>OCC1OC(c2ccc(F)c(Cc3cc4ccccc4s3)c2)C(O)C(O)C1O</smiles>

$6^{\prime}$<smiles>CCCOC[C@H]1O[C@@H](c2ccc(F)c(Cc3cc4ccccc4s3)c2)[C@H](O[Na])[C@@H](O)[C@@H]1ON</smiles>

Scheme 4: Synthesis of diastereomer 6' and 5'.

were excellent. In addition, two key diastereomers were prepared with efficient and direct access to $\alpha$ - $C$-arylglucoside and they may be served as the references both in the monitoring the reaction and the quality control of the drug.

\section{Experimental}

All solvents and reagents were of reagent grade and used without further purification. HPLC analyses were recorded using a Waters Arc HPLC System with 2998 PDA Detector or an Agilent 1260 HPLC System with DAD Detector. NMR spectra were recorded on a Bruker AV III $400 \mathrm{MHz}$ spectrometer with TMS as an internal standard. Chemical shifts are quoted in parts per million (ppm). HRMS were recorded on a Waters Q-Tof Micro LCMS apparatus. Melting points were uncorrected and measured on a Büchi Melting Piont M-565 apparatus. Optical rotations were measured with an Autopol IV laboratory polarimeter.

Preparation of (1S)-1,5-anhydro-1- $\{3-[(1-b e n z o t h i o p h e n-2-$ yl)methyl]-4-fluorophenyl\}-2,3,4,6-tetra-O-pivaloyl-Dglucitol (5): A dry round-bottle flask was charged with solid $\mathrm{ZnBr}_{2}$ (16.8 g, 0.55 equiv), $\mathrm{LiBr}$ (6.5 g, 0.55 equiv) and anhydrous $n$-dibutyl ether $(120 \mathrm{~mL})$ under a nitrogen atmosphere. The resulting mixture was stirred at $50{ }^{\circ} \mathrm{C}$ until the solid dissolved, and then the mixture cooled back to room temperature and used as such for the next step. Compound 4a (50 g, $135.8 \mathrm{mmol})$ was dissolved in anhydrous toluene $(150 \mathrm{~mL})$ and $n$-dibutyl ether $(90 \mathrm{~mL})$ under nitrogen atmosphere, and then 
the mixture was cooled to $-20{ }^{\circ} \mathrm{C}, n$-butyllithium in hexane $2.5 \mathrm{M}(57.6 \mathrm{~mL}, 1.06$ equiv) was added dropwise over $20 \mathrm{~min}$. After beeing stirred for $3 \mathrm{~h}$, a solution of $\mathrm{ZnBr}_{2}-\mathrm{LiBr}$ in $n$-dibutyl ether was added dropwise over $20 \mathrm{~min}$ at $0{ }^{\circ} \mathrm{C}$. After stirring for $1 \mathrm{~h}$, a solution of compound $\mathbf{2 b}$ ( $78.7 \mathrm{~g}, 1.0$ equiv) in toluene $(120 \mathrm{~mL})$ was added to the reaction mixture. The mixture was stirred at $100{ }^{\circ} \mathrm{C}$ for about $3 \mathrm{~h}$ until the reaction was completed (TLC detection). The mixture was quenched with $1 \mathrm{M} \mathrm{HCl}(300 \mathrm{~mL})$, and then stirred for about $10 \mathrm{~min}$ and extracted. The organic phase was washed with water $(300 \mathrm{~mL})$, followed by concentration under reduced pressure to get a brown oil. The crude oil was crystallized from methanol to get a white solid 65.7 g. Yield 65.3\%; purity (HPLC): 99.79\%; mp $133-134.7{ }^{\circ} \mathrm{C} ;[\alpha]_{\mathrm{D}}{ }^{25}=+14^{\circ}\left(c 1, \mathrm{CHCl}_{3}\right) ;{ }^{1} \mathrm{H}$ NMR $\left(400 \mathrm{MHz}, \mathrm{CDCl}_{3}\right) \delta 7.72(\mathrm{~d}, J=8.0 \mathrm{~Hz}, 1 \mathrm{H}), 7.64(\mathrm{~d}, J=8.4$ $\mathrm{Hz}, 1 \mathrm{H}), 7.31-7.22(\mathrm{~m}, 4 \mathrm{H}), 7.04(\mathrm{t}, J=9.2 \mathrm{~Hz}, 1 \mathrm{H}), 6.97$ (s, $1 \mathrm{H}), 5.40(\mathrm{t}, J=9.6 \mathrm{~Hz}, 1 \mathrm{H}), 5.33-5.23(\mathrm{~m}, 2 \mathrm{H}), 4.36(\mathrm{~d}, J=$ $10.0 \mathrm{~Hz}, 1 \mathrm{H}), 4.25-4.16(\mathrm{~m}, 3 \mathrm{H}), 4.10(\mathrm{dd}, J=12.4 \mathrm{~Hz}, 4.0 \mathrm{~Hz}$, $1 \mathrm{H}), 3.84-3.80(\mathrm{~m}, 1 \mathrm{H}), 1.19(\mathrm{~s}, 9 \mathrm{H}), 1.16(\mathrm{~s}, 9 \mathrm{H}), 1.11(\mathrm{~s}, 9 \mathrm{H})$, $0.84(\mathrm{~s}, 9 \mathrm{H}) ;{ }^{13} \mathrm{C} \mathrm{NMR}\left(100 \mathrm{MHz}, \mathrm{CDCl}_{3}\right) \delta 178.1,177.3$, $176.4,162.2,159.8,142.9,139.9,132.4,130.7,128.3,126.6$, 124.2, 123.8, 123.0, 122.0, 115.6, 80.3, 73.6, 72.0, 67.9, 61.7, 38.7, 30.0, 27.1; HRMS $\left(\mathrm{ES}^{+}\right) \mathrm{m} / z:[\mathrm{M}+\mathrm{Na}]^{+}$calcd for $\mathrm{C}_{41} \mathrm{H}_{53} \mathrm{O}_{9} \mathrm{NaSF}$, 763.3292; found, 763.3310 .

Preparation of (1S)-1,5-anhydro-1-\{3-[(1-benzothiophen-2yl)methyl]-4-fluorophenyl\}-D-glucitol (6): A round-bottom flask was charged with compound $5(20 \mathrm{~g}, 27 \mathrm{mmol})$ and methanol $(100 \mathrm{~mL})$, then, sodium methoxide ( $2.92 \mathrm{~g}, 2.0$ equiv) was added and the mixture was heated at $65{ }^{\circ} \mathrm{C}$ for $3 \mathrm{~h}$. After cooling down to room temperature, water $(300 \mathrm{~mL})$ was added to the resulting mixture, followed by addition of a seed crystal $(50 \mathrm{mg})$ and stirred for $4 \mathrm{~h}$. The crystals were filtered and dried to obtain a white solid $10.4 \mathrm{~g}$. Yield $95.3 \%$; purity (HPLC): 99.78\%; mp $155-156.5^{\circ} \mathrm{C} ;[\alpha]_{\mathrm{D}}{ }^{25}=+24.5^{\circ}\left(c 1, \mathrm{CH}_{3} \mathrm{OH}\right)$; ${ }^{1} \mathrm{H} \mathrm{NMR}\left(400 \mathrm{MHz}, \mathrm{CDCl}_{3}\right) \delta 7.73(\mathrm{~d}, J=7.6 \mathrm{~Hz}, 1 \mathrm{H}), 7.65(\mathrm{~d}$, $J=7.6 \mathrm{~Hz}, 1 \mathrm{H}), 7.45$ (dd, $J=7.2 \mathrm{~Hz}, 2.0 \mathrm{~Hz}, 1 \mathrm{H}), 7.39-7.36$ (m, $1 \mathrm{H}), 7.31-7.22(\mathrm{~m}, 2 \mathrm{H}), 7.10(\mathrm{t}, J=9.6 \mathrm{~Hz}, 1 \mathrm{H}), 7.05(\mathrm{~s}, 1 \mathrm{H})$, $4.31-4.22(\mathrm{~m}, 1 \mathrm{H}), 4.14(\mathrm{~d}, J=9.6 \mathrm{~Hz}, 1 \mathrm{H}), 3.89(\mathrm{dd}, J=12.4$ $\mathrm{Hz}, 2.0 \mathrm{~Hz}, 1 \mathrm{H}), 3.72(\mathrm{dd}, J=12.0 \mathrm{~Hz}, 5.6 \mathrm{~Hz}, 1 \mathrm{H}), 3.51-3.33$ $(\mathrm{m}, 4 \mathrm{H}) ;{ }^{13} \mathrm{C} \mathrm{NMR}\left(100 \mathrm{MHz}, \mathrm{CDCl}_{3}\right) \delta 161.6,159.2,143.6$, $140.1,139.7,135.8,130.4,128.0,126.1,123.8,123.4,122.6$, 121.6, 114.5, 81.5, 80.8, 78.4, 75.1, 70.5, 61.7, 29.3; HRMS $\left(\mathrm{ES}^{+}\right) \mathrm{m} / z:[\mathrm{M}+\mathrm{Na}]^{+}$calcd for $\mathrm{C}_{21} \mathrm{H}_{21} \mathrm{O}_{5} \mathrm{NaSF}, 427.0991$; found, 427.0983 .

Preparation of ipragliflozin L-proline (1): A round-bottom flask was charged with compound 6 (20 g, $49.4 \mathrm{mmol})$, and filled up with ethanol $(100 \mathrm{~mL})$, and then L-proline $(5.7 \mathrm{~g}$, 1.0 equiv) and water $(10 \mathrm{~mL})$ were added. The mixture was stirred at $100{ }^{\circ} \mathrm{C}$ for $0.5 \mathrm{~h}$. Thereafter, the reaction solution was cooled to room temperature, and crystallized to get a white solid 21.5 g. Yield $83.7 \%$; purity (HPLC): $99.92 \%$; decomposition temperature $203.3-205{ }^{\circ} \mathrm{C} ;[\alpha]_{\mathrm{D}}{ }^{25}=-9.2^{\circ}(c$ 1, acetonitrile/ $\left.\mathrm{H}_{2} \mathrm{O} 7: 3\right) ;{ }^{1} \mathrm{H}$ NMR $\left(400 \mathrm{MHz}, \mathrm{CDCl}_{3}\right) \delta 7.75(\mathrm{~d}, J=8.0 \mathrm{~Hz}$, $1 \mathrm{H}), 7.67(\mathrm{~d}, J=7.2 \mathrm{~Hz}, 1 \mathrm{H}), 7.45(\mathrm{~d}, J=7.6 \mathrm{~Hz}, 2.4 \mathrm{~Hz}, 1 \mathrm{H})$, $7.39-7.36(\mathrm{~m}, 1 \mathrm{H}), 7.31-7.23(\mathrm{~m}, 2 \mathrm{H}), 7.10(\mathrm{t}, J=9.2 \mathrm{~Hz}, 1 \mathrm{H})$, $7.07(\mathrm{~s}, 1 \mathrm{H}), 4.32-4.23(\mathrm{~m}, 2 \mathrm{H}), 4.14(\mathrm{~d}, J=9.2 \mathrm{~Hz}, 1 \mathrm{H})$, 4.00-3.97 (m, 1H), 3.89 (dd, $J=12.0 \mathrm{~Hz}, 1.6 \mathrm{~Hz}, 1 \mathrm{H}), 3.71$ (dd, $J=12.0 \mathrm{~Hz}, 5.2 \mathrm{~Hz}, 1 \mathrm{H}), 3.50-3.31(\mathrm{~m}, 5 \mathrm{H}), 3.27-3.20(\mathrm{~m}$, $1 \mathrm{H}), 2.35-2.26(\mathrm{~m}, 1 \mathrm{H}), 2.17-2.09(\mathrm{~m}, 1 \mathrm{H}), 2.01-1.94(\mathrm{~m}, 2 \mathrm{H})$; ${ }^{13} \mathrm{C}$ NMR $\left(100 \mathrm{MHz}, \mathrm{CDCl}_{3}\right) \delta 172.6,161.6,159.2,143.6$, $139.9,135.9,130.4,127.9,126.0,123.8,123.4,122.6,121.5$, $114.5,81.5,80.8,78.4,75.1,70.5,61.5,45.6,29.2,23.7$; MS $\left(\mathrm{ES}^{+}\right) \mathrm{m} / z: 427.16[\mathrm{M}+\mathrm{Na}]^{+}$

Preparation of (1R)-1,5-anhydro-1-\{3-[(1-benzothiophen-2yl)methyl]-4-fluorophenyl\}-3,4,6-tri-O-pivaloyl-D-glucitol (8): A dry round-bottom flask was charged with solid $\mathrm{ZnBr}_{2}$ ( $2.59 \mathrm{~g}, 1.15$ equiv), $\mathrm{LiBr}$ ( $1 \mathrm{~g}, 1.15$ equiv) and anhydrous $n$-dibutyl ether $(15 \mathrm{~mL})$ under nitrogen atmosphere, the resulting mixture was stirred at $50{ }^{\circ} \mathrm{C}$ for $2 \mathrm{~h}$. After cooling to room temperature, the mixture was used as such for the next step. A solution of compound $4 \mathbf{a}$ (4.05 g, 1.1 equiv) dissolved in anhydrous toluene $(20 \mathrm{~mL})$ under nitrogen atmosphere was cooled to $0{ }^{\circ} \mathrm{C}, n$-butyllithium in hexane $1.6 \mathrm{M}(7.2 \mathrm{~mL}, 1.15$ equiv) was added dropwise over $8 \mathrm{~min}$. After beeing stirred for $2 \mathrm{~h}$, a solution of $\mathrm{ZnBr}_{2}-\mathrm{LiBr}$ in $n$-dibutyl ether was added dropwise over $10 \mathrm{~min}$ at $0{ }^{\circ} \mathrm{C}$. After being stirred for $1.5 \mathrm{~h}$, a solution of compound $7(4.15 \mathrm{~g}, 10 \mathrm{mmol})$ in toluene $(10 \mathrm{~mL})$ was added to the reaction mixture. The mixture was stirred at room temperature for about $14 \mathrm{~h}$, then saturated ammonium chloride $(50 \mathrm{~mL})$ was added (quenched the reaction), the organic phase was washed with water, dried over $\mathrm{Na}_{2} \mathrm{SO}_{4}$ and concentrated under reduced pressure. The residue was purified by column chromatography to afford the title compound as light yellow oil 1.316 g. Yield $20 \%$; purity (HPLC): $98.2 \% ;[\alpha]_{\mathrm{D}}{ }^{25}=+21.5^{\circ}$ (c $\left.1, \mathrm{CHCl}_{3}\right) ;{ }^{1} \mathrm{H}$ NMR $\left(400 \mathrm{MHz}, \mathrm{CDCl}_{3}\right) \delta 7.72(\mathrm{~d}, J=8.0$ $\mathrm{Hz}, 1 \mathrm{H}), 7.64(\mathrm{~d}, J=7.2 \mathrm{~Hz}, 1 \mathrm{H}), 7.46-7.39(\mathrm{~m}, 2 \mathrm{H}), 7.30-7.23$ $(\mathrm{m}, 2 \mathrm{H}), 7.07(\mathrm{t}, J=9.2 \mathrm{~Hz}, 1 \mathrm{H}), 7.01(\mathrm{~s}, 1 \mathrm{H}), 5.24(\mathrm{t}, J=6.0$ $\mathrm{Hz}, 1 \mathrm{H}), 5.06(\mathrm{~d}, J=2.8 \mathrm{~Hz}, 1 \mathrm{H}), 4.96(\mathrm{t}, J=4.8 \mathrm{~Hz}, 1 \mathrm{H}), 4.57$ (m, 1H), 4.29-4.20 (m, 2H), 4.05-3.97 (m, 3H), 2.51 (brs, 1H), $1.24(\mathrm{~s}, 9 \mathrm{H}), 1.19(\mathrm{~s}, 9 \mathrm{H}), 1.14(\mathrm{~s}, 9 \mathrm{H}) ;{ }^{13} \mathrm{C} \mathrm{NMR}(100 \mathrm{MHz}$, $\left.\mathrm{CDCl}_{3}\right) \delta 178.1,177.4,176.6,161.5,159.1,143.3,140.0$, $139.7,133.0,130.1,127.7,126.6,123.9,123.0,122.1,121.8$, $115.5,72.8,71.9,71.0,69.9,67.2,60.7,38.8,30.2,27.1$; MS $\left(\mathrm{ES}^{-}\right) \mathrm{m} / z: 691.09[\mathrm{M}+\mathrm{Cl}]^{-}$.

Preparation of (1R)-1,5-anhydro-1-\{3-[(1-benzothiophen-2yl)methyl]-4-fluorophenyl\}-D-glucitol (6'): A round-bottom flask was charged with compound 8 (1.316 g, $2 \mathrm{mmol})$ and filled up with methanol $(7 \mathrm{~mL})$, and then sodium methoxide 
( $0.324 \mathrm{~g}, 3.0$ equiv) was added, the resulting mixture was heated at $65{ }^{\circ} \mathrm{C}$ for $3 \mathrm{~h}$. After cooling down to room temperature, the reaction was quenched with a solution of ammonium chloride $(10 \mathrm{wt} \%, 15 \mathrm{~mL})$. The aqueous layer was extracted with ethyl acetate $(15 \mathrm{~mL})$. The organic layer was washed with water, dried over $\mathrm{Na}_{2} \mathrm{SO}_{4}$ and concentrated under reduced pressure. The residue was purified by column chromatography to afford the title compound as light yellow solid $0.602 \mathrm{~g}$. Yield 74.4\%; purity (HPLC): 99.8\%; mp 164.5-167.6 ${ }^{\circ} \mathrm{C}$; $[\alpha]_{\mathrm{D}}^{25}=+55.5^{\circ}(c 1, \mathrm{MeOH}) ;{ }^{1} \mathrm{H} \mathrm{NMR}\left(400 \mathrm{MHz}, \mathrm{CD}_{3} \mathrm{OD}\right) \delta$ $7.74(\mathrm{~d}, J=7.6 \mathrm{~Hz}, 2 \mathrm{H}), 7.70-7.66(\mathrm{~m}, 2 \mathrm{H}), 7.31-7.22(\mathrm{~m}, 2 \mathrm{H})$, $7.10-7.06(\mathrm{~m}, 2 \mathrm{H}), 5.08(\mathrm{~d}, J=4.0 \mathrm{~Hz}, 1 \mathrm{H}), 4.26(\mathrm{~s}, 2 \mathrm{H})$, 3.90-3.83 (m, 2H), 3.79-3.69 (m, 2H), 3.48-3.42 (m, 2H); ${ }^{13} \mathrm{C}$ NMR $\left(100 \mathrm{MHz}, \mathrm{CD}_{3} \mathrm{OD}\right) \delta 161.1,158.6,143.7,140.1$, $139.7,134.8,130.9,128.6,126.0,123.8,123.4,122.6,121.5$, $114.4,75.7,73.7,72.9,61.1,29.4 ; \mathrm{MS}\left(\mathrm{ES}^{+}\right) \mathrm{m} / z: 427.33$ $[\mathrm{M}+\mathrm{Na}]^{+}$.

Preparation of (1R)-1,5-anhydro-1-\{3-[(1-benzothiophen-2yl)methyl]-4-fluorophenyl $\}-2,3,4,6$-tetra- $O$-pivaloyl-Dglucitol (5'): In a round-bottom flask, a mixture of compound 8 ( $1 \mathrm{~g}, 1.52 \mathrm{mmol})$, DCM ( $5 \mathrm{~mL})$, DMAP (10 mg, 0.05 equiv) and TEA ( $0.46 \mathrm{~g}, 3.0$ equiv) were stirred at room temperature. Then, pivaloyl chloride ( $0.55 \mathrm{~g}, 3.0$ equiv) was added dropwise and the mixture was stirred at room temperature for 5 days, the reaction was diluted with DCM $(10 \mathrm{~mL})$ and quenched with saturated ammonium chloride $(10 \mathrm{~mL})$, the organic layer was washed with water, dried over $\mathrm{Na}_{2} \mathrm{SO}_{4}$ and concentrated under reduced pressure. The residue was purified by column chromatography to afford the title compound as light yellow solid 0.596 g. Yield 52.84\%; purity (HPLC): $95.7 \%$; mp 159.2-162.3 ${ }^{\circ} \mathrm{C} ;[\alpha]_{\mathrm{D}}{ }^{25}=+78.9^{\circ}\left(\mathrm{c} 1, \mathrm{CHCl}_{3}\right) ;{ }^{1} \mathrm{H} \mathrm{NMR}$ $\left(400 \mathrm{MHz}, \mathrm{CDCl}_{3}\right) \delta 7.72(\mathrm{~d}, J=8 \mathrm{~Hz}, 1 \mathrm{H}), 7.65(\mathrm{~d}, J=7.6 \mathrm{~Hz}$, $1 \mathrm{H}), 7.59(\mathrm{dd}, J=6.8 \mathrm{~Hz}, 1.6 \mathrm{~Hz}, 1 \mathrm{H}), 7.52-7.48(\mathrm{~m}, 1 \mathrm{H})$, $7.30-7.22(\mathrm{~m}, 2 \mathrm{H}), 7.12-7.07(\mathrm{~m}, 2 \mathrm{H}), 5.69$ (t, $J=9.2 \mathrm{~Hz}, 1 \mathrm{H})$, $5.35(\mathrm{dd}, J=9.2 \mathrm{~Hz}, 5.6 \mathrm{~Hz}, 1 \mathrm{H}), 5.29(\mathrm{~d}, J=6.0 \mathrm{~Hz}, 1 \mathrm{H}), 5.16$ (t, $J=9.2 \mathrm{~Hz}, 1 \mathrm{H}), 4.31-4.23(\mathrm{~m}, 2 \mathrm{H}), 4.11-4.02(\mathrm{~m}, 2 \mathrm{H})$, $3.64-3.60(\mathrm{~m}, 1 \mathrm{H}), 1.18(\mathrm{~s}, 9 \mathrm{H}), 1.17$ (s, 9H), $1.13(\mathrm{~s}, 9 \mathrm{H}), 0.92$ $(\mathrm{s}, 9 \mathrm{H}) ;{ }^{13} \mathrm{C}$ NMR $\left(100 \mathrm{MHz}, \mathrm{CDCl}_{3}\right) \delta 178.0,177.1,176.6$, $161.6,159.1,142.8,139.9,131.4,129.0,126.9,124.0,123.1$, 122.1, 115.7, 73.1, 70.6, 68.4, 62.1, 38.7, 30.0, 27.0; $\mathrm{MS}_{\left(\mathrm{ES}^{+}\right)}$ $m / z: 763.44[\mathrm{M}+\mathrm{Na}]^{+}$.

\section{Supporting Information}

\section{Supporting Information File 1}

${ }^{1} \mathrm{H}$ NMR, ${ }^{13} \mathrm{C}$ NMR and HRMS spectra of compounds $\mathbf{1 ,}, \mathbf{5}$, $\mathbf{6}, \mathbf{5}, \mathbf{6}$, and $\mathbf{8}$, and HPLC diagram of $\mathbf{5}$.

[http://www.beilstein-journals.org/bjoc/content/ supplementary/1860-5397-13-105-S1.pdf]

\section{References}

1. Plosker, G. L. Drugs 2014, 74, 2191-2209. doi:10.1007/s40265-014-0324-3

2. Plosker, G. L. Drugs 2014, 74, 807-824. doi:10.1007/s40265-014-0225-5

3. Scott, L. J. Drugs 2014, 74, 1769-1784. doi:10.1007/s40265-014-0298-1

4. Poole, R. M.; Dungo, R. T. Drugs 2014, 74, 611-617. doi:10.1007/s40265-014-0204-x

5. Poole, R. M.; Prossler, J. E. Drugs 2014, 74, 939-944 doi:10.1007/s40265-014-0229-1

6. Markham, A.; Elkinson, S. Drugs 2014, 74, 945-950. doi:10.1007/s40265-014-0230-8

7. Ohkura, T. World J. Diabetes 2015, 6, 136-144. doi:10.4239/wjd.v6.i1.136

8. Hedrington, M. S.; Davis, S. N. Expert Opin. Drug Metab. Toxicol. 2015, 11, 613-623. doi:10.1517/17425255.2015.1009893

9. Kousuke, K.; Atsushi, N.; Makoto, K.; Masakazu, I.; Ryota, S.; Keita, N. Method for producing C-Glycoside derivative and intermediate for synthesis thereof. U.S. Patent 20100094025, April 15, 2010.

10. Imamura, M.; Nakanishi, K.; Suzuki, T.; Ikegai, K.; Shiraki, R.; Ogiyama, T.; Murakami, T.; Kurosaki, E.; Noda, A.; Kobayashi, Y.; Yokota, M.; Koide, T.; Kosakai, K.; Ohkura, Y.; Takeuchi, M.; Tomiyama, H.; Ohta, M. Bioorg. Med. Chem. 2012, 20, 3263-3279. doi:10.1016/j.bmc.2012.03.051

11. Wang, X.-j.; Zhang, L.; Byrne, D.; Nummy, L.; Weber, D.; Krishnamurthy, D.; Yee, N.; Senanayake, C. H. Org. Lett. 2014, 16, 4090-4093. doi:10.1021/ol501755h

12. Lemarie, S.; Houpis, I. N.; Xiao, T.; Li, J.; Digard, E.; Gozlan, C.; Liu, R.; Gavryushin, A.; Diène, C.; Wang, Y.; Farina, V.; Knochel, P. Org. Lett. 2012, 14, 1480-1483. doi:10.1021/ol300220p

13. Henschke, J. P.; Wu, P.-Y.; Lin, C.-W.; Chen, S.-F.; Chiang, P.-C.; Hsiao, C.-N. J. Org. Chem. 2015, 80, 2295-2309. doi:10.1021/jo502839e

14. Zhu, F.; Rourke, M. J.; Yang, T.; Rodriguez, J.; Walczak, M. A. J. Am. Chem. Soc. 2016, 138, 12049-12052. doi:10.1021/jacs.6b07891

15. Gong, H. G.; Gagné, M. R. J. Am. Chem. Soc. 2008, 130, 12177-12183. doi:10.1021/ja8041564

16. Kunz, H.; Harreus, A. Liebigs Ann. Chem. 1982, 41-48. doi:10.1002/jlac.198219820105

17. Wang, Q.; Fu, J.; Zhang, J. Carbohydr. Res. 2008, 343, 2989-2991. doi:10.1016/j.carres.2008.08.037

18. Sato, K.; Oka, N.; Fujita, S.; Matsumura, F.; Wada, T. J. Org. Chem. 2010, 75, 2147-2156. doi:10.1021/jo902725g

19. Prescribing information "Suglat tablet 25mg". Tokyo, Japan, 2016; https://amn.astellas.jp/jp/di/list/sgl/if_sgl.pdf (accessed Dec 11, 2016).

20. Wagschal, S.; Guilbaud, J.; Rabet, P.; Farina, V.; Lemaire, S. J. Org. Chem. 2015, 80, 9328-9335. doi:10.1021/acs.joc.5b01472 


\section{License and Terms}

This is an Open Access article under the terms of the Creative Commons Attribution License

(http://creativecommons.org/licenses/by/4.0), which permits unrestricted use, distribution, and reproduction in any medium, provided the original work is properly cited.

The license is subject to the Beilstein Journal of Organic Chemistry terms and conditions:

(http://www.beilstein-journals.org/bjoc)

The definitive version of this article is the electronic one which can be found at:

doi:10.3762/bjoc.13.105 